\title{
The Impact of Hydrogen Peroxide Against Cucumber Green Mottle Mosaic Virus Infection in Watermelon Plants
}

\author{
Deya Eldeen Mohammed Radwan ${ }^{1,2 *}$, Khatib Sayeed Ismail ${ }^{2}$ \\ ${ }^{1}$ Botany Department, Faculty of Science, Sohag University, Sohag, Egypt \\ ${ }^{2}$ Virology Section, Biology Department, Faculty of Science, Jazan University, Jazan, Kingdom of Saudi Arabia
}

Received: 8 November 2019

Accepted: 15 December 2019

\begin{abstract}
The aim of this work was to study the effects of hydrogen peroxide $\left(\mathrm{H}_{2} \mathrm{O}_{2}\right)$ application against cucumber green mottle mosaic virus (CGMMV) infection in watermelon (Citrullus lanatus) plants. From the obtained results, the induced resistance using $\mathrm{H}_{2} \mathrm{O}_{2}$ treatments caused a delay in the appearance of CGMMV symptoms in watermelon plants. The viral infection showed abnormal morphological symptoms such as mosaics, yellow blisters and reduction in size. Pretreatment with $\mathrm{H}_{2} \mathrm{O}_{2}$ before infection was beneficial in increasing the contents of pigments, total proteins, total free amino acids and proline. Consequently, plants appeared morphologically similar to healthy controls. Signaling the effect of the $\mathrm{H}_{2} \mathrm{O}_{2}$ treatment could induce partial resistance or delay the appearance of symptoms and decreased virus concentration. The induced mechanism of resistance was suggested to be through alterations of plant antioxidant status - both enzymatic and non-enzymatic. All analyzed antioxidant enzymes were induced in response to $\mathrm{H}_{2} \mathrm{O}_{2} \pm$ CGMMV. Due to the $\mathrm{H}_{2} \mathrm{O}_{2}$ application prior to infection, malondialdehyde (MDA) content was reduced, indicating a lowering in lipid peroxidation caused by virus infection. On the other hand, internal $\mathrm{H}_{2} \mathrm{O}_{2}$ and phenolics contents were induced in $\mathrm{H}_{2} \mathrm{O}_{2}+\mathrm{CGMMV-treated} \mathrm{leaves.}$ To confirm: total antioxidant activity was increased to be double the value (80.67\%) of that recorded in healthy plants (47.18\%), indicating changes in antioxidant status as a response to $\mathrm{H}_{2} \mathrm{O}_{2}$ and/or CGMMV infection. This work provided evidence of the signaling role of exogenous $\mathrm{H}_{2} \mathrm{O}_{2}$, which led to systemic acquired resistance (SAR) induction acting against CGMMV infection in watermelon plants. From the present findings, a suggestion of spraying of $\mathrm{H}_{2} \mathrm{O}_{2}$ might be helpful in avoiding the appearance of CGMMV severe symptoms throughout the plants' life.
\end{abstract}

Keywords: cucumber green mottle mosaic virus, hydrogen peroxide, systemic acquired resistance, antioxidant enzymes, phenolics, malondialdehyde, antioxidant activity

*e-mail: deya90@yahoo.com 


\section{Introduction}

Cucumber green mottle mosaic virus (CGMMV) is one of the major cucurbit viral diseases resulting in economic losses in cucurbit production worldwide. CGMMV belongs to the Tobamovirus genus that systemically infects many cucurbitaceous plants such as watermelon (Citrullus lanatus), cucumber (Cucumis sativus), pumpkin (Cucurbita pepo), squash (Cucurbita moschata) and bottle gourd (Lagenaria siceraria) [1, 2]. CGMMV is spread and transferred easily by many ways, including mechanical transfer, foliage contact, soil contamination, propagation materials, pollen grains and infected seeds [3-6]. Although there is no insect vector that transmits CGMMV, the widespread nature of the virus is due to the stability of virus particles for a long period under extreme conditions. CGMMV disease causes severe symptoms, including mottling, mosaics, distortion, blistering of leaves and discoloration, and deterioration of the internal part of watermelon fruits - making them undesirable for marketing [1].

Less is known about induced resistance to CGMMV in cucurbit plants, as there are no commercial melon cultivars resistant to CGMMV. Moreover, there are no chemicals used to avoid the spread of CGMMV; only methyl bromide has been used for soil disinfection of CGMMV and has been restricted since 2005. A kind of resistance against CGMMV-SH strain was reported by Crespo et al., [7] in C. sativus accessions through restriction of movement of the virus within the plant. Induction of systemic acquired resistance (SAR) provides immunity against viral infection. SAR induction is a good way to control virus spread. Chemical elicitors of SAR (such as salicylic acid, benzoic acid, aminobenzoic acid, oligomers of chitosan, etc.) provide resistance against different virus classes [8]. The mechanism of SAR defense might be through callose deposition and hydrogen peroxide $\left(\mathrm{H}_{2} \mathrm{O}_{2}\right)$ production, which acts as a signal molecule in a plant that activates pathogenesis-related gene expression.

The signaling effect of hydrogen peroxide is well reported as a fast response of plant defense mechanism [9]. Hydrogen peroxide is important for physiological processes of plants. It can control stress responses and systemic signaling $[10,11]$. Production of hydrogen peroxide is an early response to environmental stressors due to alterations in biochemical processes $[12,13]$. Under stress, hydrogen peroxide is produced in response to oxidative stress. It is a safe form of reactive oxygen species (ROS), where cells can be controlled by an antioxidant enzymatic system. In plant-pathogen interaction, cellular signaling via ROS is generated. Hydrogen peroxide is a non-radical type of reactive oxygen species (ROS). Due to its diffusibility it can move across membranes and reach numerous biomolecules and affect the activity of proteins and act as a signaling factor. $\mathrm{H}_{2} \mathrm{O}_{2}$ operates as an oxidant or reductant in many cellular reactions. It can transfer across membranes passively or through water channels [14]. Hydrogen peroxide is less toxic than other ROSs. It is scavenged by $\mathrm{H}_{2} \mathrm{O}_{2}$ scavenging enzymes such as catalase, peroxidase and ascorbate peroxidase. As an enzymatic antioxidant, catalase plays a key role in preventing cellular oxidative damage by degrading hydrogen peroxide $\left(\mathrm{H}_{2} \mathrm{O}_{2}\right)$ into water and oxygen with high efficiency [15]. Pan et al. [16] reported exogenous application of $\mathrm{H}_{2} \mathrm{O}_{2}$ in Arabidopsis thaliana, which can activate signaling pathways able to produce antioxidants [10]. Recently, it was reported that $\mathrm{H}_{2} \mathrm{O}_{2}$ can induce gene expression and enzymatic defense responses in pepper plants $[17,18]$.

This work was to proove that a protective role of hydrogen peroxide was generated through the induction of SAR in watermelon plants against CGMMV. This role was explained in this article through alterations of both enzymatic and non-enzymatic antioxidant status of plants.

\section{Materials and Methods}

\section{Plant Material and Treatments}

A six-week experiment was carried out to test the effects of hydrogen peroxide (Sigma Aldrich, USA. 50 wt. $\%$ in $\mathrm{H}_{2} \mathrm{O}$ ) in induction of resistance against CGMMV-SH infection in watermelon plants. Seeds of Citrullus lanatus (cv. Malali) were germinated in soil (sand and clay $3: 1$ ) in $3 \mathrm{~L}$ pots in a greenhouse. Completely randomized design was used in this study. Three weeks after planting, plants were grouped into 6 groups (each group consists of 4 pots containing 3-4 plants, sampling from 4 independent plants). Groups were treated according to the following:

1. Control: Plants were sprayed with tap water.

2. Infected: Plants were treated with tap water one day prior CGMMV inoculation.

3. $10 \mathrm{mM} \mathrm{H}_{2} \mathrm{O}_{2}$ : Plants were sprayed with $10 \mathrm{mM}$ solution of $\mathrm{H}_{2} \mathrm{O}_{2}$.

4. $5 \mathrm{mM} \mathrm{H} \mathrm{H}_{2} \mathrm{O}_{2}+\mathrm{V}$ : Plants were sprayed with $5 \mathrm{mM}$ solution of $\mathrm{H}_{2} \mathrm{O}_{2}$ one day prior inoculation.

5. $10 \mathrm{mM} \mathrm{H}_{2} \mathrm{O}_{2}+\mathrm{V}$ : Plants were sprayed with $10 \mathrm{mM}$ solution of $\mathrm{H}_{2} \mathrm{O}_{2}$ one day prior inoculation.

6. $20 \mathrm{mM} \mathrm{H}_{2} \mathrm{O}_{2}+\mathrm{V}$ : Plants were sprayed with $20 \mathrm{mM}$ solution of $\mathrm{H}_{2} \mathrm{O}_{2}$ one day prior inoculation.

For inoculation, freshly infected leaves found to be positive for CGMMV were ground in a mortar containing $0.1 \mathrm{M}$ phosphate buffer of $\mathrm{pH}=7.0$ $(1: 2 \mathrm{w} / \mathrm{v})$. The homogenate was then filtrated through two layers of muslin. Plants were dusted with 600-mesh carborundum and rubbed gently with a cotton swap previously dipped into the suspension of virus inoculum [1]. Plants were inoculated once throughout the experimental period. Control plants were treated with carborundum and phosphate buffer only. Natural infections were avoided by keeping plants in isolated controlled conditions (growth chamber). Plants were 
kept at $20 \pm 2^{\circ} \mathrm{C}$ and $65 \%$ humidity in a growth chamber. Symptoms appeared two weeks after inoculation. Leaf samples were photographed and taken for analyses after three weeks of virus inoculation (i.e., at the end of this experiment).

\section{DAS- ELISA for CGMMV Detection}

100 Healthy and infected plants were subjected to a DAS-ELISA test (double antibody sandwichedenzyme linked immunosorbent assay) [19]. A ready for use kits (Agdia Inc., Madison, USA) were used to analyze the samples. All the buffers, coating antibodies and conjugated antibodies were diluted as the protocol provided by the manufacturer. Absorbance at $405 \mathrm{~nm}$ was determined with a plate reader for all samples at the same time.

\section{Percentage of Infection and Severity of Symptoms}

Three weeks after inoculation the percentage of infected plants and the severity of symptoms were examined using the following rating scale: $0=$ no symptoms; 1 = chlorotic local lesions and mild mosaic; $2=$ severe mosaic and $3=$ blisters and malformation. Disease severity values were calculated using the following equation [20]:

Disease severity $($ DS $)=\frac{\sum(\text { disease grade } \times \text { number of plants in each grade })}{(\text { Total number of plants } \times \text { highest disease grade })}$

Three weeks after inoculation the youngest fully developed leaves from both control and treated plants were sampled for biochemical analyses.

\section{Photosynthetic Pigments Content}

The analysis of Chlorophyll A (Chl A), Chlorophyll B (Chl B) and Carotenoids (Cars) was carried out using the Lichtenthaler and Buschmann Method [21]. Fresh leaves $(0.1 \mathrm{~g})$ of control and treated fresh leaves were extracted by grinding in $10 \mathrm{ml}$ acetone $(85 \%)$ in a mortar. The extract was centrifuged at $5000 \mathrm{rpm}$. Supernatant was separated in a test tube for analysis. Pigment extract was then analyzed by colorimeter (T80 UV-VIS spectrophotometer, PG Instruments, UK) using three wavelengths: 663, 647 and $470 \mathrm{~nm}$.

The absorbance of the extracts was then used to calculate pigment concentrations through the following formulas:

$$
\begin{aligned}
& \text { Chlorophyll } a=12.25 \mathrm{~A}_{663}-2.79 \mathrm{~A}_{647} \\
& \text { Chlorophyll } b=21.50 \mathrm{~A}_{647}-5.10 \mathrm{~A}_{663} \\
& \text { Carotenoids }=\left(1000 \mathrm{~A}_{470}-1.82 * \mathrm{Chl} \mathrm{a}\right. \\
& -95.151 * \mathrm{Chl} \mathrm{b}) / 225
\end{aligned}
$$

The contents of pigments were calculated as $\mathrm{mg} \mathrm{g}^{-1} \mathrm{FW}$.

\section{Antioxidant Enzyme Analyses}

Fresh leaves $(0.5 \mathrm{~g})$ of control and treated plants were extracted in $10 \mathrm{ml}$ of phosphate buffer $(\mathrm{pH}=7.0)$ by grinding in a mortar. The extract was then centrifuged at $14000 \mathrm{rpm}$ in cool conditions $4^{\circ} \mathrm{C}$ for $20 \mathrm{~min}$. The supernatant was separated and prepared for analysis of antioxidant enzymes (peroxidase; POD, catalase; CAT, ascorbate peroxidase; APX and superoxide dismutase; SOD).

For analysis of POD activity we used the Zhang [22] method. The extract was added to the analyzing medium containing $5 \mathrm{mM}$ guaiacol, $0.3 \mathrm{mM}$ hydrogen peroxide, and $0.1 \mathrm{mM}$ EDTA in $40 \mathrm{mM}$ phosphate buffer $(\mathrm{pH}=7.2)$. The increase in oxidation of guiacol was analyzed at $470 \mathrm{~nm}$ using a UV-VIS spectrophotometer (T80, PG Instruments, UK). Using the extinction factor $=26.2 \mathrm{mM} \mathrm{cm}^{-1}$, the POD activity was calculated as $\mu \mathrm{mol}$ of guiacol oxidized $\mathrm{min}^{-1} \mathrm{~g}^{-1} \mathrm{FW}$.

In the case of CAT activity we used the Chandlee and Scandalios method [23]. The enzyme extract was mixed with the assay medium that contained $10 \mathrm{mM}$ $\mathrm{H}_{2} \mathrm{O}_{2}$ in $25 \mathrm{mM}$ potassium phosphate buffer ( $\mathrm{pH}$ 7.0). The rate of decomposition of $\mathrm{H}_{2} \mathrm{O}_{2}$ was then detected at

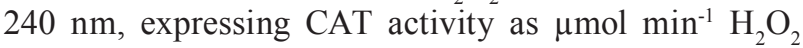
(Extinction factor $=0.036 \mathrm{mM}^{-1} \mathrm{~cm}^{-1}$ ).

For APX activity analysis we used the method of Nakano and Asada [24]. The assay medium consisted of $0.3 \mathrm{mM}$ ascorbate, $0.1 \mathrm{mM}$ EDTA, and $0.06 \mathrm{mM} \mathrm{H}_{2} \mathrm{O}_{2}$ in $50 \mathrm{mM}$ phosphate buffer ( $\mathrm{pH} 7.0)$. The analysis was based on the decrease of ascorbate by determination of the decline in absorbance at $290 \mathrm{~nm}$ (extinction factor $=2.8 \mathrm{mM}^{-1} \mathrm{~cm}^{-1}$ ).

SOD activity was determined using the Beauchamp and Fridovich [25] method. The extract was added to the assay medium, which contained $9.9 \mathrm{mM}$ L-methionine, $0.025 \% \quad(\mathrm{w} / \mathrm{v})$ nitroblue tetrazolium (NBT), and $0.0044 \%(\mathrm{w} / \mathrm{v})$ riboflavin in $50 \mathrm{mM}$ phosphate buffer ( $\mathrm{pH}$ 7.8). Photo-reduction of NBT (purple color) was analyzed at $560 \mathrm{~nm}$. One unit of SOD enzyme extract caused $50 \%$ inhibition of photoreduction of NBT.

\section{Antioxidant Metabolites MDA and $\mathrm{H}_{2} \mathrm{O}_{2}$}

Malondialdehyde (MDA) content was determined in leaves by the Zhang method [22]. Fresh leaves were extracted in 5\% TCA (trichloroacetic acid), followed by $10 \mathrm{~min}$ centrifugation at $3000 \mathrm{rpm}$. The supernatant was then mixed with $0.03 \mathrm{mM}$ of 2-thiobarbituric acid (TBA) and incubated at $94^{\circ} \mathrm{C}$ for $15 \mathrm{~min}$. After cooling, the developed color was then analyzed by spectrophotometer at $532 \mathrm{~nm}$. Using extinction factor $\left(E=155 \mathrm{mM} \mathrm{cm}^{-1}\right)$, the MDA concentration was calculated as nmol MDA g $\mathrm{g}^{-1} \mathrm{FW}$.

Hydrogen peroxide $\left(\mathrm{H}_{2} \mathrm{O}_{2}\right)$ content was determined by using the method of Jana and Choudhuri [26]. Leaves were extracted in $50 \mathrm{mM}$ phosphate buffer $(\mathrm{pH}=6.5)$ and centrifuged at $6000 \mathrm{~g}$ for $25 \mathrm{~min}$. The supernatant 
was mixed with $1 \mathrm{ml}$ of $0.1 \%$ titanium sulfate in $20 \% \mathrm{H}_{2} \mathrm{SO}_{4}$ after the ppt formation; the mixture was centrifuged at $6000 \mathrm{~g}$ for $15 \mathrm{~min}$. The pellet was then dissolved in $5 \mathrm{ml} \mathrm{H}_{2} \mathrm{SO}_{4}(2 \mathrm{M})$ and the absorbance was then measured by spectrophotometer at $410 \mathrm{~nm}$. Using the extinction coefficient $\left(E=0.28 \mu \mathrm{mol}^{-1} \mathrm{~cm}^{-1}\right), \mathrm{H}_{2} \mathrm{O}_{2}$ content was calculated as nmol g-1 FW.

\section{Phenolics Content}

A folin- Ciocalteau reagent was used to determine the content of phenolics in control, infected and treated leaves. The method of Singleton and Rossi [27] was used. Extracts were prepared in methanol (80\%) and mixed with $1.8 \mathrm{ml}$ of Folin-Ciocalteu reagent (diluted 1:10) and stand for $5 \mathrm{~min}$ at room temperature. $1.2 \mathrm{ml}$ of $\mathrm{NaHCO}_{3}(7.5 \% \mathrm{w} / \mathrm{v})$ was added. Color was analyzed at $765 \mathrm{~nm}$ after standing for $60 \mathrm{~min}$ at room temperature. Phenolic contents were presented as $\mu \mathrm{g} \mathrm{GAEg}^{-1} \mathrm{DW}$, where GAE is the equivalent of gallic acid.

\section{Assay of Total Antioxidant Activity}

DPPH (1,1-diphenyl-2-picrylhydrazyl, Sigma Aldrich) free radical scavenging assay test was used to analyze the antioxidant status of control and treated leaves [28]. Fresh leaves were extracted in methanol and mixed with a similar amount of freshly prepared DPPH solution (80 ppm in methanol). After mixing thoroughly, tubes were kept in the dark for $30 \mathrm{~min}$. The color was then determined by spectrophotometer at $517 \mathrm{~nm}$. Using the following equation, total antioxidant activity was calculated as a percentage of DPPH scavenging activity:

$$
\text { Antioxidant activity }=\left[1-\left(\mathrm{A}_{\mathrm{i}}-\mathrm{A}_{\mathrm{j}}\right) / \mathrm{A}_{\mathrm{c}}\right] * 100
$$

...where $\mathrm{A}_{\mathrm{i}}$ is absorbance of extract $+\mathrm{DPPH}, \mathrm{A}_{\mathrm{j}}$ ia the absorbance of extract + methanol and $A_{c}$ is absorbance of DPPH + methanol.

\section{Proteins Content}

Total proteins content of control, infected and $\mathrm{H}_{2} \mathrm{O}_{2}$-treated leaves were analyzed using the Lowry method [29]. Samples were extracted in $\mathrm{NaOH}(0.1 \mathrm{~N})$ in water bath $\left(100^{\circ} \mathrm{C}\right)$ for $1 \mathrm{hr}$. The extracts were centrifuged at $4000 \mathrm{rpm}$ and the supernatant was taken for analysis. Alkaline-Folin reagent was used. One $\mathrm{ml}$ of extract was mixed with $5 \mathrm{ml}$ of alkaline reagent prepared as follows (reagent $\mathrm{A}: 2 \% \mathrm{Na}_{2} \mathrm{CO}_{3}$ in $0.1 \mathrm{~N} \mathrm{NaOH}$ and reagent B: $0.5 \% \mathrm{CuSO}_{4}$ in Sod. Pot. Tartrate). After standing $20 \mathrm{~min}$ the folin reagent $0.5 \mathrm{ml}$ was added and mixed thoroughly and left to stand for $20 \mathrm{~min}$. Absorption was determined at $750 \mathrm{~nm}$. Total protein contents were expressed as $\mathrm{mg} / \mathrm{g}$ dry weight of leaves.

\section{Total Free Amino Acids}

The Moore and Stein [30] method was used to analyze the free amino acids of different leaves. Tissue samples were extracted in distilled water by heating in a water bath at $90^{\circ} \mathrm{C}$ for $2 \mathrm{hrs}$. The extracts were then centrifuged and the supernatants were collected. Supernatant was added to $1 \mathrm{~mL}$ of ninhydrin solution with stannous chloride. The mix was heated in a boiling water bath for 20min.; a purple color developed. Diluents $(5 \mathrm{~mL})$ were added and contents were mixed. Fifteen minutes later, the developed color was read at $570 \mathrm{~nm}$ against blank. The free amino acid concentrations were calculated as $\mathrm{mg} / \mathrm{g}$ dry matter.

\section{Proline Content}

The method of Bates et al. [31] was used to determine the proline content control, infected and $\mathrm{H}_{2} \mathrm{O}_{2}$-treated leaves. The extract was prepared using $0.1 \mathrm{~g}$ of dried powdered leaves in $10 \mathrm{ml}$ of $3 \%$ sulfosalicylic acid for $12 \mathrm{~h}$. Centrifuging was carried out for $10 \mathrm{~min}$ at $1500 \mathrm{rpm}$. For analysis, supernatants were mixed with acid ninhydrin reagent $+2 \mathrm{ml}$ glacial acetic acid and heated in a water bath at $100^{\circ} \mathrm{C}$ for $1 \mathrm{~h}$. Cooling of the mixture using ice bath then $4 \mathrm{ml}$ toluene were added for extraction of the pink color. The absorbance was measured at $520 \mathrm{~nm}$ for toluene phase containing the color. Proline content was calculated as ug $\mathrm{g}^{-1}$ DW using a pre-analyzed standard curve using proline amino acid.

\section{Statistical Analysis}

The results were reported as mean $\pm \mathrm{SD}$ of four independent replicates. Statistical analyses of data were carried out by computer using SPSS ver. 23.0 software. One-way ANOVA and least significant differences test (LSD) for multiple comparisons were used to evaluate the differences among the means.

\section{Results}

\section{Morphological Changes and Growth Analysis}

Fifteen days after inoculation, leaves became mosaic with green and yellow blisters and were reduced in size compared to the control (Fig. 1). The leaf was mostly yellow with heavy hairy surface - especially in the petiole and leaf edges. Infected leaf area was reduced to $79 \%$ less than control. Treatment with $\mathrm{H}_{2} \mathrm{O}_{2}$ without infection increased leaf area to $12 \%$ more than control. The application of $20 \mathrm{mM} \mathrm{H}_{2} \mathrm{O}_{2}$ prior to infection made it able to keep the leaf area similar to control. Analysis of shoot length revealed a severe decrease by 55\% compared to control. $\mathrm{H}_{2} \mathrm{O}_{2} \pm$ infection treatment was able to increase shoot length. In detail, shoot lengths were increased by $78 \%$ more than control with $20 \mathrm{mM} \mathrm{H}_{2} \mathrm{O}_{2}$, 

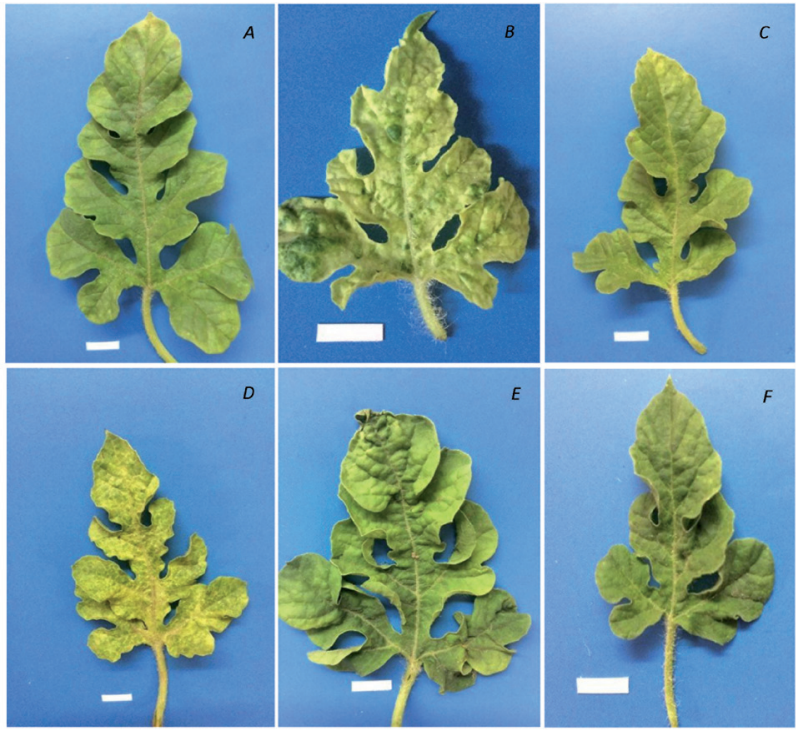

Fig. 1. Effects of CGMMV infection and $\mathrm{H}_{2} \mathrm{O}_{2}$ treatments on leaf morphology and severity of symptoms of watermelon leaves. Control (A) shows healthy appearance; infected (B) shows mosaics and blisters; $10 \mathrm{mM} \mathrm{H}_{2} \mathrm{O}_{2}$ (C) shows healthy appearance; $5 \mathrm{mM} \mathrm{H} \mathrm{H}_{2}+$ inf (D) shows mild symptoms; $10 \mathrm{mM} \mathrm{H}_{2} \mathrm{O}_{2}+\inf (\mathrm{E})$ shows no symptoms; and $20 \mathrm{mM} \mathrm{H}_{2} \mathrm{O}_{2}$ $+\inf (\mathrm{F})$ shows no symptoms. Scale bar $(1 \mathrm{~cm})$.

followed by GCMMV infection. A decrease in leaf area and shoot length of the infected plants led to an obvious decrease in dry matter. Lowered dry matter of watermelon plants by $49 \%$ was recorded with infection. In contrast, a gradual increase in dry matter was noticed with $\mathrm{H}_{2} \mathrm{O}_{2}$ treatment followed by infection. Spraying $20 \mathrm{mM} \mathrm{H} \mathrm{H}_{2}$ before infection was able to increase dry matter by up to $60 \%$ more than control (Table 1 ). Changes in water content of infected and $\mathrm{H}_{2} \mathrm{O}_{2}$-treated plants was observed. A highly significant decrease of water content in both infected and $\left(5 \mathrm{mM} \mathrm{H}_{2} \mathrm{O}_{2}+\right.$ inf $)$ plants was noticed, while $20 \mathrm{mM} \mathrm{H}_{2} \mathrm{O}_{2}$ followed by infection was almost similar to the control (Table 1).
Both percentage of infection and disease severity showed a noticeable decrease with $\mathrm{H}_{2} \mathrm{O}_{2}$ pretreatment in inoculated plants. Although all concentrations of $\mathrm{H}_{2} \mathrm{O}_{2}$ (5-20) were able to decrease the infection percentage, the most effective concentration was the highest one $\left(20 \mathrm{mM} \mathrm{H}_{2} \mathrm{O}_{2}\right)$. This concentration was able to minimize the percentage of infection and lowered the severity of disease (Table 2). The concentration of CGMMV virus using the ELISA test showed positive results in infected and $\left(\mathrm{H}_{2} \mathrm{O}_{2}+\right.$ virus $)$ treated leaves. This means the appearance of symptoms in plants with different degrees according to the detected concentration of the virus. It was noticed that the concentration declined gradually by increasing the applied $\mathrm{H}_{2} \mathrm{O}_{2}$ dose (Table 2).

\section{Photosynthetic Pigments Content}

The analyzed photosynthetic pigment contents in infected leaves showed a highly significant reduction in Chl A, Chl B and Carotenoids (Fig. 2). This reduction reached $50 \%$ of control in $\mathrm{Chl} \mathrm{A}$ and carotenoids due to virus infection. The use of $\mathrm{H}_{2} \mathrm{O}_{2}$ without a virus showed a highly significant increase of photosynthetic pigment contents $(55,39$ and $25 \%$ more than control in case of $\mathrm{Chl} \mathrm{A,} \mathrm{Chl} \mathrm{B} \mathrm{and} \mathrm{cars,} \mathrm{respectively).} \mathrm{On} \mathrm{the} \mathrm{other}$ hand, $\mathrm{H}_{2} \mathrm{O}_{2}$ treatments followed by virus infection could pronouncedly increase the contents of photosynthetic pigments. It was noticeable that the increase in pigments was concomitant with $\mathrm{H}_{2} \mathrm{O}_{2}$ concentrations - especially in Chl A and Chl B. It is noticeable that 10 and $20 \mathrm{mM} \mathrm{H} \mathrm{H}_{2}+$ infections were more effective in pigment content improvement. The most obvious result was obtained with the treatment $20 \mathrm{mM}$ $\mathrm{H}_{2} \mathrm{O}_{2}+$ virus infection, which led to increasing Chl A, Chl B and carotenoids to be 69,94 and $42 \%$ more than their corresponding controls (Fig. 2).

Table 1. Effect of CGMMV infection and $\mathrm{H}_{2} \mathrm{O}_{2}$ treatments on Leaf area $\left(\mathrm{cm}^{2}\right.$ plant $\left.{ }^{-1}\right)$, Shoot length $\left(\mathrm{cm} \mathrm{plant}^{-1}\right)$, Water content $(\%)$ and Dry matter $\left(\mathrm{g} \mathrm{plant}^{-1}\right)$ of watermelon plants. The values are means $(\mathrm{M})$ of four replicates \pm standard deviation (SD). The values are means (M) of four replicates \pm standard deviation (SD).

\begin{tabular}{|c|c|c|c|c|c|c|c|}
\hline \multirow{2}{*}{ Treatments } & \multicolumn{2}{|c|}{$\begin{array}{l}\text { Leaf area } \\
\left(\mathrm{cm}^{2} \text { plant }{ }^{-1}\right)\end{array}$} & \multicolumn{2}{|c|}{$\begin{array}{l}\text { Shoot length } \\
\left(\mathrm{cm}^{\left.-1 a n t^{-1}\right)}\right.\end{array}$} & \multirow{2}{*}{$\begin{array}{c}\text { Water content } \\
(\%)\end{array}$} & \multicolumn{2}{|c|}{$\begin{array}{l}\text { Dry matter } \\
\left(\text { g plant }^{-1}\right)\end{array}$} \\
\hline & $\mathrm{M} \pm \mathrm{SD}$ & $\%$ & $\mathrm{M} \pm \mathrm{SD}$ & $\%$ & & $\mathrm{M} \pm \mathrm{SD}$ & $\%$ \\
\hline Control & $105.92 \pm 9.87$ & 100 & $43.64 \pm 5.38$ & 100 & $87.34 \pm 0.49$ & $3.73 \pm 0.09$ & 100 \\
\hline Infected & $22.15 * * \pm 12.67$ & 20.91 & $19.87 * * \pm 4.39$ & 45.53 & $76.48 * * \pm 1.94$ & $1.93 * * \pm 0.04$ & 51.74 \\
\hline $10 \mathrm{mM} \mathrm{H}_{2} \mathrm{O}_{2}$ & $111.37 \pm 11.65$ & 105.15 & $45.65 \pm 6.34$ & 104.61 & $89.95 \pm 0.72$ & $3.99 \pm 0.02$ & 106.97 \\
\hline $5 \mathrm{mM} \mathrm{H}_{2} \mathrm{O}_{2}+\mathrm{inf}$ & $78.29 * * \pm 8.23$ & 73.91 & $62.59 * * \pm 2.85$ & 143.42 & $77.13 * * \pm 0.81$ & $4.32 * \pm 0.06$ & 115.82 \\
\hline $10 \mathrm{mM} \mathrm{H}_{2} \mathrm{O}_{2}+\inf$ & $96.17 * \pm 15.74$ & 90.79 & $69.13^{* *} \pm 3.46$ & 158.41 & $83.85^{*} \pm 0.95$ & $5.72 * * \pm 0.03$ & 153.35 \\
\hline $20 \mathrm{mM} \mathrm{H}_{2} \mathrm{O}_{2}+\inf$ & $100.33 \pm 10.63$ & 94.72 & $77.62 * * \pm 4.64$ & 177.86 & $87.54 \pm 0.37$ & $5.98 * * \pm 0.05$ & 160.32 \\
\hline
\end{tabular}

Statistical significance of differences compared to control: *, significant at $P<0.05$; **, significant at $P<0.01$. 
Table 2. Effect of CGMMV infection and $\mathrm{H}_{2} \mathrm{O}_{2}$ treatments on Percentage of infection (\%), Disease severity (\%) and Virus concentration using ELISA test of watermelon plants. The values are means $(\mathrm{M})$ of four replicates \pm standard deviation (SD).

\begin{tabular}{|c|c|c|c|}
\hline \multirow{2}{*}{ Treatments } & $\begin{array}{c}\text { Percentage of infection } \\
(\%)\end{array}$ & $\begin{array}{c}\text { Disease severity } \\
(\%) \\
\end{array}$ & Virus concentration* \\
\hline & $M \pm S D$ & $M$ & $M \pm S D$ \\
\hline Infected & $97.54 \pm 3.27$ & 74.65 & $1.273 \pm 0.175$ \\
\hline $5 \mathrm{mM} \mathrm{H}_{2} \mathrm{O}_{2}+\inf$ & $66.18 * * \pm 2.65$ & 33.89 & $0.932 \pm 0.065$ \\
\hline $10 \mathrm{mM} \mathrm{H}_{2} \mathrm{O}_{2}+\mathrm{inf}$ & $13.87 * * \pm 0.64$ & 12.7 & $0.645 \pm 0.028$ \\
\hline $20 \mathrm{mM} \mathrm{H}_{2} \mathrm{O}_{2}+\inf$ & $4.83 * * \pm 0.45$ & 1.97 & $0.193 \pm 0.056$ \\
\hline
\end{tabular}

Statistical significance of differences compared to control: *, significant at $P<0.05$; **, significant at $P<0.01$. *ELISA test for virus concentration, the positive and negative controls are 1.497 and 0.105 respectively; Positive control means infected leaves showed symptoms typically. And negative control means infected leaves showed no symptoms

\section{Antioxidant Enzyme Activities POD and CAT Activities}

Activities of POD and CAT were induced significantly in the infected leaf samples (Table 3). The activities were almost doubled in response to infection. With all $\mathrm{H}_{2} \mathrm{O}_{2}$ treatments, POD and CAT showed enhanced activities compared to control.

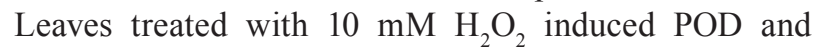
CAT activities to be $86 \%$ and $80 \%$ more than those of control, respectively. A highly significant increase in POD and CAT activities was noticed with the increase of $\mathrm{H}_{2} \mathrm{O}_{2}$ treatment followed by infection. This increase reached $182 \%$ (POD) and $118 \%$ (CAT) more than control in the case of spraying $20 \mathrm{mM} \mathrm{H}_{2} \mathrm{O}_{2}$ prior to infection.

\section{APX and SOD Activities}

It was noticeable that APX activity in infected leaves was highly induced (Table 3). Compared to control, APX activity was 3-fold higher (220\% increase) in response to GCMMV infection. SOD activity increased by $25 \%$ more than control due to virus infection. Inductions of APX and SOD activities were recorded in leaves treated with $10 \mathrm{mM} \mathrm{H}_{2} \mathrm{O}_{2}$ without infection. The application of $\mathrm{H}_{2} \mathrm{O}_{2}(5-20 \mathrm{mM})$ followed by infection caused a concomitant decrease in APX activity. On the

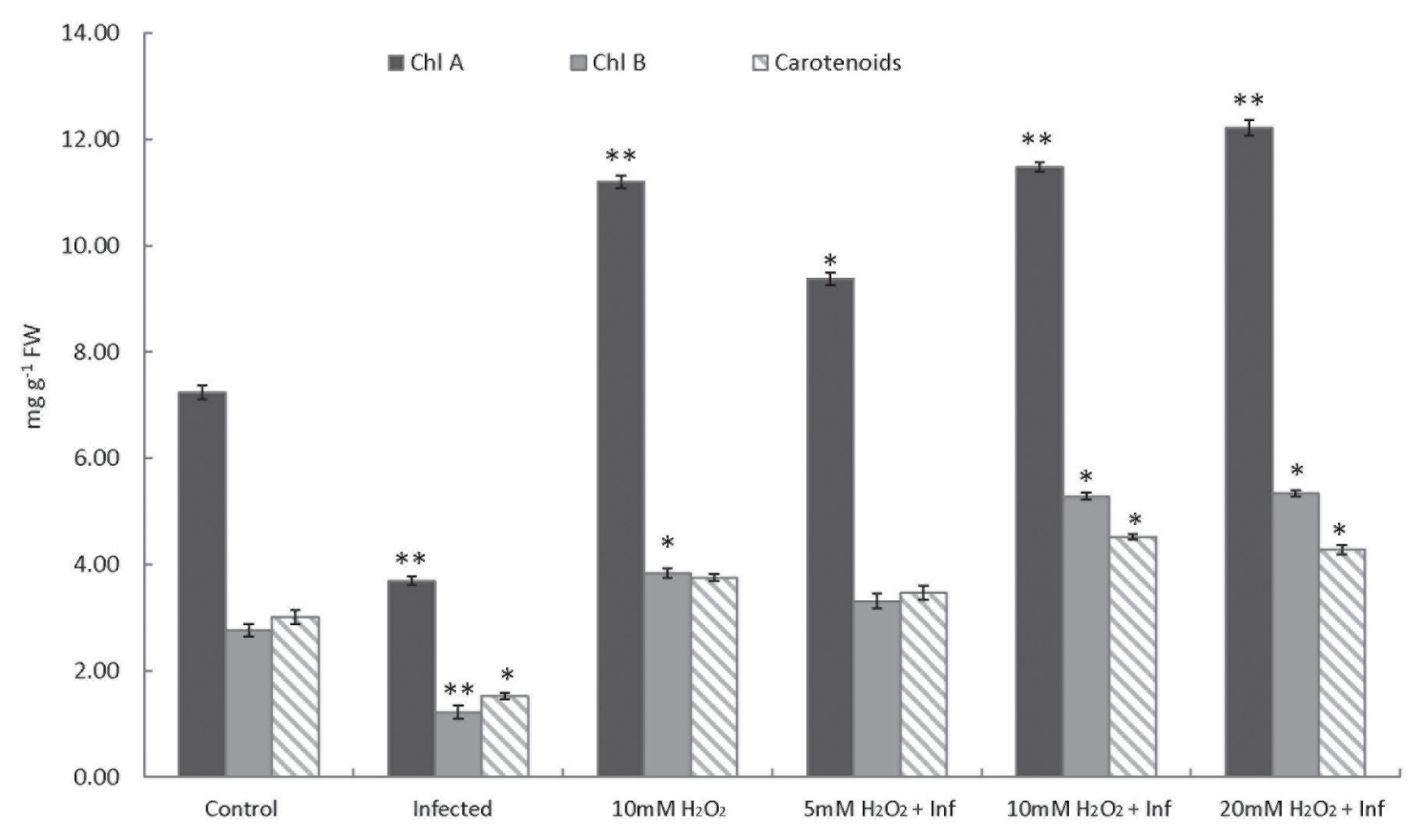

Treatments

Fig. 2. Effects of CGMMV infection and $\mathrm{H}_{2} \mathrm{O}_{2}$ treatment of pigment contents (Chl a, Chl b and Carotenoids) (mg g $\left.\mathrm{g}^{-1} \mathrm{FW}\right)$ of watermelon leaves. The values are means of four replicates \pm standard deviation. Statistical significance of differences compared to control: *, significant at $P<0.05$; **, significant at $P<0.01$. 
Table 3. Effect of CGMMV infection and $\mathrm{H}_{2} \mathrm{O}_{2}$ treatments on Peroxidase, Catalase, Ascorbate Peroxidase and Superoxide dismutase activities (Unit $\mathrm{g}^{-1} \mathrm{FW}$ ) of watermelon plants. The values are means (M) of four replicates \pm standard deviation (SD). The values are means (M) of four replicates \pm standard deviation (SD).

\begin{tabular}{|c|c|c|c|c|c|c|c|c|}
\hline \multirow{2}{*}{ Treatments } & \multicolumn{2}{|c|}{ POD (Unit g-1 FW) } & \multicolumn{2}{|c|}{ CAT (Unit $\mathrm{g}^{-1} \mathrm{FW}$ ) } & \multicolumn{2}{|c|}{ APX (Unit g $\left.{ }^{-1} \mathrm{FW}\right)$} & \multicolumn{2}{|c|}{ SOD (Unit g-1 FW) } \\
\hline & $M \pm S D$ & $\%$ & $M \pm S D$ & $\%$ & $\mathrm{M} \pm \mathrm{SD}$ & $\%$ & $\mathrm{M} \pm \mathrm{SD}$ & $\%$ \\
\hline Control & $94.83 \pm 3.27$ & 100 & $43.64 \pm 2.94$ & 100.00 & $48.86 \pm 1.75$ & 100 & $54.64 \pm 0.71$ & 100 \\
\hline Infected & $187.07 * * \pm 6.34$ & 197.27 & $88.41 * * \pm 0.57$ & 202.59 & $156.34 * * \pm 0.58$ & 319.98 & $68.74 * * \pm 0.20$ & 125.81 \\
\hline $10 \mathrm{mM} \mathrm{H}_{2} \mathrm{O}_{2}$ & $176.42 * * \pm 4.83$ & 186.04 & $78.60 * * \pm 0.22$ & 180.11 & $86.45^{* *} \pm 0.49$ & 176.93 & $83.39 * * \pm 0.54$ & 152.62 \\
\hline $5 \mathrm{mM} \mathrm{H}_{2} \mathrm{O}_{2}+\mathrm{inf}$ & $234.53 * * \pm 3.62$ & 247.32 & $86.37 * * \pm 0.84$ & 197.91 & $75.83 * * \pm 1.22$ & 155.20 & $95.84 * * \pm 1.03$ & 175.40 \\
\hline $10 \mathrm{mM} \mathrm{H}_{2} \mathrm{O}_{2}+\mathrm{inf}$ & $274.36^{* *} \pm 8.75$ & 289.32 & $93.76^{* *} \pm 0.74$ & 214.85 & $66.90 * \pm 0.37$ & 136.92 & $101.45^{* *} \pm 2.62$ & 185.67 \\
\hline $20 \mathrm{mM} \mathrm{H}_{2} \mathrm{O}_{2}+\mathrm{inf}$ & $266.95 * * \pm 5.83$ & 281.50 & $95.04 * * \pm 1.53$ & 217.78 & $83.54 \pm 0.45$ & 170.98 & $131.64 * * \pm 1.66$ & 240.92 \\
\hline
\end{tabular}

other hand, leaves treated with $\mathrm{H}_{2} \mathrm{O}_{2}$ only showed higher SOD activities compared to the control. Moreover, an increase of $(141 \%)$ more than control was recorded in SOD activity in watermelon leaves sprayed with $20 \mathrm{mM}$ $\mathrm{H}_{2} \mathrm{O}_{2}$ plus infection.

\section{Antioxidant Metabolites MDA and $\mathrm{H}_{2} \mathrm{O}_{2}$}

The amounts of both MDA and $\mathrm{H}_{2} \mathrm{O}_{2}$ were analyzed in control and treated leaves (Table 4). MDA was commonly used as an indicator for lipid peroxidation and oxidative stress. An increase in MDA content was noticed with infection (about 37\% more than control). The use of $\mathrm{H}_{2} \mathrm{O}_{2}$ prior to infection showed variable results. $\mathrm{H}_{2} \mathrm{O}_{2}$ without infection was able to lower the MDA content by $5 \%$, but with infection MDA contents increased even if pretreated with $\mathrm{H}_{2} \mathrm{O}_{2}$. On the other side, $\mathrm{H}_{2} \mathrm{O}_{2}$ content increased as a response to infection ( $65 \%$ more). Pretreatments with $\mathrm{H}_{2} \mathrm{O}_{2} \pm$ infection were able to accumulate $\mathrm{H}_{2} \mathrm{O}_{2}$ and the amounts were dose-dependent. The highest amount of $\mathrm{H}_{2} \mathrm{O}_{2}$ was recorded in leaves treated with $20 \mathrm{mM} \mathrm{H}_{2} \mathrm{O}_{2}$ followed by infection. Compared with the amounts present in infected leaves, $\mathrm{H}_{2} \mathrm{O}_{2}$ couldn't record the same ratio of increase with the applied $\mathrm{H}_{2} \mathrm{O}_{2}$ concentrations.

\section{Total Phenolics and Antioxidant Activity}

Analysis of phenolics content in control and GCMMV-infected leaves revealed the accumulation of amounts of phenolics in infected leaves by $45 \%$ (Table 4). Treatment with $20 \mathrm{mM} \mathrm{H} \mathrm{H}_{2}$ without virus infection was able to increase phenolics slightly (9\%), while $20 \mathrm{mM} \mathrm{H}_{2} \mathrm{O}_{2}$ plus infection increased phenolics content by $23 \%$ more than control. With all concentrations of $\mathrm{H}_{2} \mathrm{O}_{2}$ followed by infection, the phenolics content recorded a highly significant increase that reached $22-30 \%$ more than that of control. The antioxidant activity of the tested leaves showed significant differences. In general, all treatments could increase the antioxidant activity of leaves. Infection with CGMMV induced AOA to be $66 \%$ while control leaves recorded AOA of about $47 \%$. In the case of $\mathrm{H}_{2} \mathrm{O}_{2}$ treatments, the increase in AOA was concentration dependent. Moreover, the highest improvement of AOA was noticed in leaves treated with $20 \mathrm{mM} \mathrm{H}_{2} \mathrm{O}_{2} \pm$ infection, which reached $81-85 \%$.

Table 4. Effect of CGMMV infection and $\mathrm{H}_{2} \mathrm{O}_{2}$ treatments on MDA ( $\mu$ mol MDA g-1 FW), cellular $\mathrm{H}_{2} \mathrm{O}_{2}\left(\mathrm{nmol} \mathrm{H}_{2} \mathrm{O}_{2} \mathrm{~g}^{-1} \mathrm{FW}\right)$, phenolics $\left(\mu \mathrm{g} \mathrm{g} \mathrm{g}^{-1} \mathrm{FW}\right)$ and antioxidant activity (\%) of watermelon plants. The values are means $(\mathrm{M})$ of four replicates \pm standard deviation (SD).

\begin{tabular}{|c|c|c|c|c|c|c|c|}
\hline \multirow{2}{*}{ Treatments } & \multicolumn{2}{|c|}{$\operatorname{MDA}\left(\mu \mathrm{mol} \mathrm{MDA} \mathrm{g}{ }^{-1} \mathrm{FW}\right)$} & \multicolumn{2}{|c|}{$\mathrm{H}_{2} \mathrm{O}_{2}\left(\mathrm{nmol} \mathrm{H} \mathrm{H}_{2} \mathrm{O} \mathrm{g}^{-1} \mathrm{FW}\right)$} & \multicolumn{2}{|c|}{ Total Phenolics $\left(\mu \mathrm{gg}^{-1} \mathrm{FW}\right)$} & $\mathrm{AOA}(\%)$ \\
\hline & $\mathrm{M} \pm \mathrm{SD}$ & $\%$ & $\mathrm{M} \pm \mathrm{SD}$ & $\%$ & $\mathrm{M} \pm \mathrm{SD}$ & $\%$ & $\mathrm{M} \pm \mathrm{SD}$ \\
\hline Control & $15.64 \pm 0.93$ & 100.00 & $19.72 \pm 0.38$ & 100.00 & $53.89 \pm 1.38$ & 100.00 & $47.18 \pm 1.94$ \\
\hline Infected & $26.37 * * \pm 1.43$ & 136.64 & $32.54 * * \pm 1.56$ & 165.01 & $78.34 * * \pm 2.91$ & 145.37 & $65.92 * * \pm 3.51$ \\
\hline $10 \mathrm{mM} \mathrm{H}_{2} \mathrm{O}_{2}$ & $14.82 \pm 0.56$ & 94.76 & $21.32 \pm 0.52$ & 108.11 & $58.74 * \pm 3.09$ & 109.00 & $85.10 * * \pm 2.75$ \\
\hline $5 \mathrm{mM} \mathrm{H}_{2} \mathrm{O}_{2}+\mathrm{inf}$ & $21.34 * \pm 0.71$ & 136.45 & $23.96 * \pm 0.45$ & 121.50 & $67.61 * * \pm 2.80$ & 125.46 & $69.27 * * \pm 2.06$ \\
\hline $10 \mathrm{mM} \mathrm{H}_{2} \mathrm{O}_{2}+\mathrm{inf}$ & $21.95 * \pm 0.65$ & 140.35 & $25.63 * \pm 0.71$ & 129.97 & $69.92 * * \pm 2.81$ & 129.75 & $71.85 * * \pm 1.83$ \\
\hline $20 \mathrm{mM} \mathrm{H}_{2} \mathrm{O}_{2}+\mathrm{inf}$ & $19.84 * \pm 1.06$ & 126.85 & $26.45 * \pm 0.87$ & 134.13 & $65.74 * * \pm 3.63$ & 121.99 & $80.67 * * \pm 2.90$ \\
\hline
\end{tabular}


Table 5. Effect of CGMMV infection and $\mathrm{H}_{2} \mathrm{O}_{2}$ treatments on Total proteins ( $\left.\mathrm{mg} \mathrm{g}^{-1} \mathrm{FW}\right)$, Total free amino acids ( $\left.\mathrm{mg} \mathrm{g}^{-1} \mathrm{DW}\right)$ and Proline $\left(\mathrm{mg} \mathrm{g}^{-1} \mathrm{DW}\right)$ contents of watermelon plants. The values are means $(\mathrm{M})$ of four replicates \pm standard deviation (SD).

\begin{tabular}{|c|c|c|c|c|c|c|}
\hline \multirow{2}{*}{ Treatments } & \multicolumn{2}{|c|}{ Total proteins ( $\left.\mathrm{mg} \mathrm{g}^{-1} \mathrm{DW}\right)$} & \multicolumn{2}{|c|}{ Total free amino acids ( $\left.\mathrm{mg} \mathrm{g}^{-1} \mathrm{DW}\right)$} & \multicolumn{2}{|c|}{ Proline content (mg g-1 DW) } \\
\hline & $\mathrm{M} \pm \mathrm{SD}$ & $\%$ & $\mathrm{M} \pm \mathrm{SD}$ & $\%$ & $\mathrm{M} \pm \mathrm{SD}$ & $\%$ \\
\hline Control & $218.78 \pm 12.54$ & 100.00 & $38.17 \pm 0.30$ & 100.00 & $1.18 \pm 0.01$ & 100.00 \\
\hline Infected & $276.81 * \pm 11.65$ & 126.52 & $55.95^{* *} \pm 0.64$ & 146.58 & $3.27 * * \pm 0.03$ & 277.12 \\
\hline $10 \mathrm{mM} \mathrm{H}_{2} \mathrm{O}_{2}$ & $332.16^{* *} \pm 17.83$ & 152.82 & $47.29 * \pm 0.48$ & 123.89 & $2.48 * \pm 0.02$ & 210.17 \\
\hline $5 \mathrm{mM} \mathrm{H}_{2} \mathrm{O}_{2}+\mathrm{inf}$ & $302.53 * * \pm 32.45$ & 138.28 & $48.37 * \pm 0.25$ & 126.72 & $2.76^{* *} \pm 0.04$ & 233.90 \\
\hline $10 \mathrm{mM} \mathrm{H}_{2} \mathrm{O}_{2}+$ inf & $354.34 * * \pm 18.38$ & 161.96 & $56.68 * * \pm 0.63$ & 148.49 & $2.68 * \pm 0.03$ & 227.12 \\
\hline $20 \mathrm{mM} \mathrm{H}_{2} \mathrm{O}_{2}+\inf$ & $365.45 * * \pm 19.59$ & 167.04 & $60.86 * * \pm 0.55$ & 159.44 & $2.37 * \pm 0.04$ & 200.85 \\
\hline
\end{tabular}

Statistical significance of differences compared to control: *, significant at $P<0.05 ; * *$, significant at $P<0.01$.

\section{Total Proteins, Total Free Amino Acids and Proline Contents}

The amounts of total proteins are presented in Table 5. Infected leaves showed significant accumulation of proteins due to infection. In infected leaves, the increase in proteins reached $27 \%$ more than control. $\mathrm{H}_{2} \mathrm{O}_{2}$ treatment prior to infection was able to raise the protein content. In detail, the application of $5 \mathrm{mM} \mathrm{H} \mathrm{H}_{2}+$ infection caused a $38 \%$ increase and $20 \mathrm{mM} \mathrm{H} \mathrm{H}_{2} \mathrm{O}_{2}+$ infection caused a $67 \%$ increase compared to control. Similar to proteins, free amino acid contents followed the same behavior of increase in treated samples. The free amino acid of infected leaves reached $47 \%$ more than the control. All $\mathrm{H}_{2} \mathrm{O}_{2}$ concentrations \pm infection caused the accumulation of more amounts of free amino acids. The accumulation was $59 \%$ more than the content of control in infected leaves pretreated with $20 \mathrm{mM} \mathrm{H}_{2} \mathrm{O}_{2}$. As proline accumulation is considered an indication of the presence of stress conditions, the analysis of proline in infected leaves showed a highly significant increase $(177 \%$ more than control). Plants responded to $\mathrm{H}_{2} \mathrm{O}_{2}$ treatments (with or without infection) by increasing the proline content. For example, treatment with $20 \mathrm{mM} \mathrm{H}_{2} \mathrm{O}_{2}$ alone was able to increase proline content to be $110 \%$ more than that of control. On the other hand, treatment with $20 \mathrm{mM} \mathrm{H}_{2} \mathrm{O}_{2}$ followed by infection was able to increase the proline content to $101 \%$ compared to that of control.

\section{Discussion}

Induction of systemic acquired resistance (SAR) in plants is an efficient way to resist pathogen infection. SAR occurs in many plant species in response to pathogen infection and the application of certain chemicals. SAR is associated with the expression of plant defense genes [32]. Chemical elicitors can generate systemic signals that lead to SAR induction. Hydrogen peroxide is one of the chemical inducers of SAR, which in turn signals the formation of pathogenesis-related proteins, and phytoalexins [33]. Hydrogen peroxide and superoxide act directly as second messengers in the regulation and expression of the genes encoding proteins responsible for oxidative stress response [13]. Hydrogen peroxide is a versatile molecule that acts as a non-radical reactive oxygen species (ROS). Harmful and beneficial consequences of ROS have been recorded $[34,35]$. Hydrogen peroxide is safe and can be easily detoxified by an antioxidative enzyme system; catalase, peroxidase, ascorbate peroxidases. It is well reported that $\mathrm{H}_{2} \mathrm{O}_{2}$ plays a signaling role in plants under stress and pathogen defense [36-38] - especially against virus infection, as reported by Mejía-Teniente and Durán-Flores et al. [18]. In this work, treatment with $\mathrm{H}_{2} \mathrm{O}_{2}$ improves the growth of watermelon plants and protects against CGMMV infection. This improvement was noticed in increased growth, shoot lengths, dry matter, leaf area, minimized percentage of infection and lowered severity of disease and lowered virus concentrations. This is the first report about induced resistance using $\mathrm{H}_{2} \mathrm{O}_{2}$ treatment against CGMMV in watermelon plants.

Due to leaf CGMMV symptoms and mosaics in infected samples, the photosynthetic pigments content was significantly altered compared with control. Treatment with $\mathrm{H}_{2} \mathrm{O}_{2} \pm$ infection was able to increase amounts of chl a, chl b and carotenoids of leaves significantly. The increase was concomitant with the concentration of $\mathrm{H}_{2} \mathrm{O}_{2}$ [36], treatments with which increased PSII photochemical efficiency. Moreover, $\mathrm{H}_{2} \mathrm{O}_{2}$ treatments increased the activity of Rubisco. Increased content of pigments reflects more efficiency of photosynthesis process in plants treated with $\mathrm{H}_{2} \mathrm{O}_{2}$. In support, Ashfaque et al. [39] reported the promotion of photosynthesis in wheat plants after exogenous application of $100 \mathrm{nM} \mathrm{H}_{2} \mathrm{O}_{2}$. Moreover, treatment with $\mathrm{H}_{2} \mathrm{O}_{2}$ exogenously to quinoa plants was able to improve the photosynthesis rate by $42 \%$ and increase chlorophyll content by $36 \%$ more than the control.

In this work, a resistance mechanism against CGMMV using an exogenous application of $\mathrm{H}_{2} \mathrm{O}_{2}$ 
in watermelon plants was suggested. This induced resistance occurred through alterations of an antioxidant (enzymatic and non-enzymatic) system due to the signaling effect of $\mathrm{H}_{2} \mathrm{O}_{2}$. A significant increase of activity of POD, CAT and APX in response to $10 \mathrm{mM}$ $\mathrm{H}_{2} \mathrm{O}_{2}$ without infection was observed. The increase reached $86 \%, 80 \%$ and $77 \%$ more than control for POD, CAT and APX, respectively. On the other hand, the increase in POD, CAT, and APX with infection was $182 \%, 118 \%$, and $70 \%$ more than control. These are $\mathrm{H}_{2} \mathrm{O}_{2}$ scavenging enzymes, and increasing their activities indicates the formation or presence of more amounts of $\mathrm{H}_{2} \mathrm{O}_{2}$ [40, 41]. More increase in POD and CAT activities with $\mathrm{H}_{2} \mathrm{O}_{2}$ treatment and CGMMV was because of the double source of induction; the pathogen and exogenous $\mathrm{H}_{2} \mathrm{O}_{2}$ application. Moreover, SOD activity was induced by infection, and $\mathrm{H}_{2} \mathrm{O}_{2}$ was able to induce SOD with or without the presence of infection. SOD is induced under biotic and abiotic stress and functions in dismutation of $\mathrm{O}_{2}^{--}$to produce $\mathrm{H}_{2} \mathrm{O}_{2}$ [42]. In this work, a $26 \%$ increase in SOD activity with infection might be to avoid oxidative stress produced by infection. On the other hand, spraying $\mathrm{H}_{2} \mathrm{O}_{2}$ caused highly significant induction of SOD (141\% more than control). This is in accordance with the induced activity of $\mathrm{H}_{2} \mathrm{O}_{2}$ scavenging enzymes (POD, CAT and APX). In support are previous studies done by Clarke et al., [43] who reported changes in antioxidant activities as a response to WCIMV in Phaseolus vulgaris leaves. Moreover, changes in antioxidant enzymes were detected in biotic stress (ZYMV infection to pumpkin plants) $[44,45]$ and abiotic stress (herbicides application to peanut plants) by Radwan et al. [46]. Internal production of $\mathrm{H}_{2} \mathrm{O}_{2}$ or receiving exogenous help increased the signaling effect of $\mathrm{H}_{2} \mathrm{O}_{2}$ and induction of SAR against virus infection. Consequent to antioxidant enzymes changes, an increase in $\mathrm{H}_{2} \mathrm{O}_{2}$ levels or accumulation was noticed. This accumulation of $\mathrm{H}_{2} \mathrm{O}_{2}$ with infection and other treatments indicates oxidative stress as a response to $\mathrm{CGMMV}$ and $\mathrm{H}_{2} \mathrm{O}_{2}$ signaling cascade. As a defense to pathogen infection, radical and non-radical ROS are accumulated, triggering the oxidative burst that leads to recognition of the pathogen. $\mathrm{H}_{2} \mathrm{O}_{2}$ serves as a defensive barrier against pathogen infection [47].

MDA is a final product of fatty acid peroxidation caused by ROS accumulation [48]. MDA is used as an indicator for lipid peroxidation and oxidative stress due to the overproduction of ROS because of virus infection $[49,50]$. In the present, CGMMV infection caused the accumulation of MDA, indicating lipid peroxidation and oxidative stress. The MDA amount was lowered by exogenous spraying of $\mathrm{H}_{2} \mathrm{O}_{2}$ to the plants prior to infection. The signaling effect of $\mathrm{H}_{2} \mathrm{O}_{2}$ induces some preparatory defense mechanism prior to infection. This defense might be through the formation of special membrane proteins, preventing cell membrane peroxidation or lowering MDA amount. These proteins were induced in advance to be used further against infection. In the present study, analysis of total proteins showed the accumulation of more proteins as a response to infection and $\mathrm{H}_{2} \mathrm{O}_{2}$ spraying, i.e., protective action against infection was obtained. They are pathogenesisrelated proteins or SAR proteins. The higher the amount of $\mathrm{H}_{2} \mathrm{O}_{2}$ level, the higher the proteins accumulated. $20 \mathrm{mM} \mathrm{H}_{2} \mathrm{O}_{2}$ application followed by infection caused a $67 \%$ increase in proteins than control because of the double source of induction: treatment and infection. Proteins are among the main types of anti-plant viral substances [51]. Plants form certain proteins upon infection (pathogenesis-related proteins) to restrict pathogen growth and multiplication [52]. Pathogenesisrelated proteins are molecular markers of SAR responses [53] that can be induced both by infection through activation of PR genes and by the exogenous application of chemical elicitors. They are plant defenses in the form of SAR, which is a broad level of resistance [8]. In this work, increasing free amino acids and proline contents upon infection and/or $\mathrm{H}_{2} \mathrm{O}_{2}$ application was noticed. Li et al. [54] reported that the accumulation of amino acids is among the pathways by which different genes are responsible for interactions between CGMMV and watermelon. For most compounds, sulfer and nitrogen are mainly synthesized from amino acids [55]. In this experiment, proline amino acid analysis revealed accumulation in response to CGMMV and $\mathrm{H}_{2} \mathrm{O}_{2}$ treatments. Proline amino acid is considered an antioxidant and ROS scavenger and functions in maintaining membrane integrity and stabilizer of both antioxidant enzymes and subcellular structures [56]. It is used in activating detoxification mechanisms, and functions in the signaling process. As previously reported, proline protects against $\mathrm{H}_{2} \mathrm{O}_{2}$-induced oxidative stress of wild almond plants by increasing antioxidant enzyme activities and by decreasing MDA content and membrane damage [57].

Phenolics are among the secondary metabolites that are involved in plant protection [58]. In this study, the accumulation of phenolics content was noticed, accompanied with infection and/or $\mathrm{H}_{2} \mathrm{O}_{2}$ treatments. This is in accordance with the results obtained by $\mathrm{Li}$ and An et al. [54], who reported significant increases in phenolic compounds due to CGMMV infection. Phenolic compounds were previously reported to have antioxidizing activity providing a self-defense role under stressful conditions [59, 60]. Phenolics have the ability to alter peroxidation properties by lowering the peroxidative reaction of membranes [61]. In this experiment, the increase in phenolics related to $\mathrm{H}_{2} \mathrm{O}_{2}$ treatments can be explained as their capability of being either proton or electron donors, hence they can participate in scavenging free radicals [62]. Scavenging oxygen radicals depends on the ability of the antioxidant system of the plant. This ability to scavenge oxygen radicals is known to be inversely proportional with the levels of lipid peroxidation [63]. To confirm the effect of $\mathrm{H}_{2} \mathrm{O}_{2}$ treatment on the antioxidant status and its protective action, the total antioxidant activity was 
analyzed. It was found that the AOA was doubled to be $85 \%$ with $20 \mathrm{mM} \mathrm{H}_{2} \mathrm{O}_{2}+$ infection while the control records AOA of $47 \%$. This increase in antioxidant activity might be due to the signaling effect of $\mathrm{H}_{2} \mathrm{O}_{2}$ sprayed prior to infection, which could induce SAR through the accumulation of proteins, phenolics, proline, and free amino acids contents and alteration of antioxidant enzyme activities.

\section{Conclusions}

This work investigated the impacts of $\mathrm{H}_{2} \mathrm{O}_{2}$ treatment against CGMMV infection in watermelon plants. The treatment delayed infection and the appearance of severe CGMMV symptoms in watermelon plants. Plants treated with $\mathrm{H}_{2} \mathrm{O}_{2}+\mathrm{CGMMV}$ showed normal appearance as healthy plants during the experimental period. This can be discussed through alteration of both the enzymatic and non-enzymatic antioxidant status due to $\mathrm{H}_{2} \mathrm{O}_{2}$ treatment prior to infection. Moreover, $\mathrm{H}_{2} \mathrm{O}_{2}$ treatments lowered MDA content but accumulated proteins, free amino acids, cellular $\mathrm{H}_{2} \mathrm{O}_{2}$, proline and phenolics contents. These alterations in antioxidant status and contents of biochemical constituents due to $\mathrm{H}_{2} \mathrm{O}_{2}$ treatments can suggest a certain role of $\mathrm{H}_{2} \mathrm{O}_{2}$ in delay or resisting CGMMV infection in watermelon plants.

\section{Conflict of Interest}

The authors declare no conflict of interest.

\section{References}

1. REINGOLD V., LACHMAN O., KOREN A., DOMBROVSKY A. First report of Cucumber green mottle mosaic virus (CGMMV) symptoms in watermelon used for the discrimination of non-marketable fruits in Israeli commercial fields. New Dis. Rep. 28, 11, 2013.

2. PITMAN T., POSIS K., TIAN T., BELANGER C., ROY A., FALK B. First Report of Watermelon Green Mottle Mosaic Virus in North America. Plant Disease. PDIS, 2019.

3. LI J. X., LIU S. S., GU Q. S. Transmission efficiency of Cucumber green mottle mosaic virus via seeds, soil, pruning and irrigation water. J. Phytopathol. 164 (5), 300, 2016.

4. LIU H., LUO L., LI J., LIU P., CHEN X., HAO J. Pollen and seed transmission of Cucumber green mottle mosaic virus in cucumber. Plant Pathol. 63 (1), 72, 2014.

5. REINGOLD V., LACHMAN O., BLAOSOV E., DOMBROVSKY A. Seed disinfection treatments do not sufficiently eliminate the infectivity of Cucumber green mottle mosaic virus (CGMMV) on cucurbit seeds. Plant Pathol. 64 (2), 245, 2015.

6. WU H., QIN B., CHEN H., PENG B., CAI J., GU Q. The rate of seed contamination and transmission of Cucumber green mottle mosaic virus in watermelon and melon. Sci Agric Sin. 44 (7), 1527, 2011.
7. CRESPO O., JANSSEN D., ROBLES C., RUIZ L. Resistance to Cucumber green mottle mosaic virus in Cucumis sativus. Euphytica. 214 (11), 201, 2018.

8. TRIPATHI D., RAIKHY G., KUMAR D. Chemical Elicitors of Systemic Acquired Resistance-Salicylic Acid and Its Functional Analogs. Current Plant Biology. 2019.

9. HABIBI G. Hydrogen peroxide $\left(\mathrm{H}_{2} \mathrm{O}_{2}\right)$ generation, scavenging and signaling in plants. Oxidative Damage to Plants: Elsevierpp. 557, 2014.

10. AHMAD P. Oxidative damage to plants: antioxidant networks and signaling: Academic Press; 2014.

11. HOSSAIN M.A., BHATTACHARJEE S., ARMIN S.-M., et al. Hydrogen peroxide priming modulates abiotic oxidative stress tolerance: insights from ROS detoxification and scavenging. Frontiers in plant science. 6, 420, 2015.

12. BEN REJEB K., LEFEBVRE-DE VOS D., LE DISQUET I., et al. Hydrogen peroxide produced by NADPH oxidases increases proline accumulation during salt or mannitol stress in A rabidopsis thaliana. New Phytologist. 208 (4), 1138, 2015.

13. GUPTA K., SENGUPTA A., CHAKRABORTY M., GUPTA B. Hydrogen peroxide and polyamines act as double edged swords in plant abiotic stress responses. Frontiers in plant science. 7, 1343, 2016.

14. MILLER G., SUZUKI N., CIFTCI-YILMAZ S., MITTLER R. Reactive oxygen species homeostasis and signalling during drought and salinity stresses. Plant, Cell Environ. 33 (4), 453, 2010.

15. AHMAD P., NABI G., JELEEL C., UMAR S. Free radical production, oxidative damage and antioxidant defense mechanisms in plants under abiotic stress. Oxidative stress: role of antioxidants in plants. Studium Press, New Delhi. 19, 2011.

16. PAN J., ZHANG M., KONG X., et al. ZmMPK17, a novel maize group D MAP kinase gene, is involved in multiple stress responses. Planta. 235 (4), 661, 2012.

17. MEJÍA-TENIENTE L., DURÁN-FLORES F.D.D., CHAPA-OLIVER A., et al. Oxidative and molecular responses in Capsicum annuum L. after hydrogen peroxide, salicylic acid and chitosan foliar applications. Int. J. Mol. Sci. 14 (5), 10178, 2013.

18. MEJÍA-TENIENTE L., DURÁN-FLORES B. A., TORRES-PACHECO I., et al. Hydrogen peroxide protects pepper (Capsicum annum L.) against pepper golden mosaic geminivirus (PepGMV) infections. Physiological and Molecular Plant Pathology. 106, 23, 2019.

19. CLARK M. F., ADAMS A. Characteristics of the microplate method of enzyme-linked immunosorbent assay for the detection of plant viruses. J. Gen. Virol. 34 (3), 475, 1977.

20. LI H., DING X., WANG C., et al. Control of tomato yellow leaf curl virus disease by Enterobacter asburiaeBQ9 as a result of priming plant resistance in tomatoes. Turkish Journal of Biology. 40 (1), 150, 2016.

21. LICHTENTHALER H.K., BUSCHMANN C. Chlorophylls and carotenoids: Measurement and characterization by UV-VIS spectroscopy. Current protocols in food analytical chemistry. 2001.

22. ZHANG X., Research methodology of crop physiology. Agri. Press, Beijing, 208, 1992.

23. CHANDLEE J., SCANDALIOS J. Analysis of variants affecting the catalase developmental program in maize scutellum. Theoretical and Applied Genetics. 69 (1), 71, 1984. 
24. BEAUCHAMP C., FRIDOVICH I. Superoxide dismutase: improved assays and an assay applicable to acrylamide gels. Anal. Biochem. 44 (1), 276, 1971.

25. ZHANG X. Research methodology of crop physiology. Agri. Press, Beijing. 208, 1992.

26. JANA S., CHOUDHURI M. A. Glycolate metabolism of three submersed aquatic angiosperms during ageing. Aquat. Bot. 12, 345, 1982.

27. SINGLETON V.L., ROSSI J.A. Colorimetry of total phenolics with phosphomolybdic-phosphotungstic acid reagents. Am j Enology Viticult. 16 (3), 144, 1965.

28. SHIMADA K., FUJIKAWA K., YAHARA K., NAKAMURA T. Antioxidative properties of xanthan on the autoxidation of soybean oil in cyclodextrin emulsion. Journal of agricultural and food chemistry. 40 (6), 945, 1992

29. LOWRY O.H., ROSEBROUGH N.J., FARR A.L., RANDALL R J. Protein measurement with the Folin phenol reagent. J biol Chem. 193 (1), 265, 1951.

30. MOORE S., STEIN W.H. Photometric ninhydrin method for use in the chromatography of amino acids. Journal of biological chemistry. 176 (1), 367, 1948.

31. BATES L.S., WALDREN R.P., TEARE I. Rapid determination of free proline for water-stress studies. Plant Soil. 39 (1), 205, 1973.

32. GAO Q.-M., ZHU S., KACHROO P., KACHROO A. Signal regulators of systemic acquired resistance. Frontiers in plant science. 6, 228, 2015.

33. DUTTA H., KUMAR R.G., BORAH M. Efficacy of Biotic and Chemical Inducers of SAR in Management of Plant Viruses. 2019.

34. CHOUDHURY F.K., RIVERO R.M., BLUMWALD E., MITTLER R. Reactive oxygen species, abiotic stress and stress combination. The Plant Journal. 90 (5), 856, 2017.

35. MEKONNEN A., DEGU Y., CARLSON R. Appraisal of solvent system effect on bioactivity profiling of Cordia africana stem bark extracts. Chemistry International. 6 (1), $1,2020$.

36. KHAN T.A., YUSUF M., FARIDUDDIN Q. Hydrogen peroxide in regulation of plant metabolism: Signalling and its effect under abiotic stress. Photosynthetica. 56 (4), 1237, 2018.

37. SMIRNOFF N., ARNAUD D. Hydrogen peroxide metabolism and functions in plants. New Phytol. 221 (3), 1197, 2019.

38. SAXENA I., SRIKANTH S., CHEN Z. Cross talk between $\mathrm{H}_{2} \mathrm{O}_{2}$ and interacting signal molecules under plant stress response. Frontiers in plant science. 7, 570, 2016.

39. ASHFAQUE F., KHAN M.I.R., KHAN N.A. Exogenously applied $\mathrm{H}_{2} \mathrm{O}_{2}$ promotes proline accumulation, water relations, photosynthetic efficiency and growth of wheat (Triticum aestivum L.) under salt stress. Annual Research \& Review in Biology. 105, 2014.

40. SHARMA I., AHMAD P. Catalase: a versatile antioxidant in plants. Oxidative Damage to Plants: Elsevierpp. 131, 2014.

41. TERZI R., SARUHAN-GULER N., BISKIN N., KADIOGLU A. Exogenous Hydrogen Peroxide Alleviates Copper Toxicity by Stimulating Antioxidant System and Increases Photosynthesis Efficiency in Maize Seedlings. FEB-FRESENIUS ENVIRONMENTAL BULLETIN. 996, 2018.

42. SZÖLLŐSI R. Superoxide dismutase (SOD) and abiotic stress tolerance in plants: an overview. Oxidative Damage to Plants: Elsevierpp. 89, 2014.
43. CLARKE S.F., GUY P.L., BURRITT D.J., JAMESON P.E. Changes in the activities of antioxidant enzymes in response to virus infection and hormone treatment. Physiol. Plant. 114 (2), 157, 2002.

44. RADWAN D.E.M., LUG., FAYEZ K.A., MAHMOUD S.Y. Protective action of salicylic acid against bean yellow mosaic virus infection in Vicia faba leaves. Journal of plant physiology. 165 (8), 845, 2008.

45. RADWAN D.E.M., FAYEZ K.A., MAHMOUD S.Y., HAMAD A., LU G. Salicylic acid alleviates growth inhibition and oxidative stress caused by zucchini yellow mosaic virus infection in Cucurbita pepo leaves. Physiological and Molecular Plant Pathology. 69 (4), 172, 2006.

46. RADWAN D., MOHAMED A., FAYEZ K., ABDELRAHMAN A. Oxidative stress caused by Basagran ${ }^{\circledR}$ herbicide is altered by salicylic acid treatments in peanut plants. Heliyon. 5 (5), e01791, 2019.

47. AZARABADI S., ABDOLLAHI H., TORABI M., SALEHI Z., NASIRI J. ROS generation, oxidative burst and dynamic expression profiles of ROS-scavenging enzymes of superoxide dismutase (SOD), catalase (CAT) and ascorbate peroxidase (APX) in response to Erwinia amylovora in pear (Pyrus communis L). European Journal of Plant Pathology. 147 (2), 279, 2017.

48. SCHMID-SIEGERT E., STEPUSHENKO O., GLAUSER G., FARMER E E. Membranes as structural antioxidants recycling of malondialdehyde to its source in oxidationsensitive chloroplast fatty acids. Journal of Biological Chemistry. 291 (25), 13005, 2016.

49. RADWAN D.E.M., FAYEZ K.A., MAHMOUD S.Y., LU G. Modifications of antioxidant activity and protein composition of bean leaf due to Bean yellow mosaic virus infection and salicylic acid treatments. Acta Physiologiae Plantarum. 32 (5), 891, 2010.

50. HUSEYNOVA I., MIRZAYEVA S., SULTANOVA N., ALIYEVA D., MUSTAFAYEV N.S., ALIYEV J. Virus-induced changes in photosynthetic parameters and peroxidase isoenzyme contents in tomato (Solanum lycopersicum L.) plants. Photosynthetica. 56 (3), 841, 2018.

51. ZHAO L., FENG C., WU K., et al. Advances and prospects in biogenic substances against plant virus: a review. Pestic. Biochem. Physiol. 135, 15, 2017.

52. EL HADRAMI A., ADAM L.R., EL HADRAMI I., DAAYF F. Chitosan in plant protection. Mar. Drugs. 8 (4), 968, 2010.

53. BEKTAS Y., EULGEM T. Synthetic plant defense elicitors. Frontiers in plant science. 5, 804, 2015.

54. LI X., AN M., XIA Z., BAI X., WU Y. Transcriptome analysis of watermelon (Citrullus lanatus) fruits in response to Cucumber green mottle mosaic virus (CGMMV) infection. Sci. Rep. 7 (1), 16747, 2017.

55. HILDEBRANDT T.M., NESI A.N., ARAÚJO W.L., BRAUN H.-P. Amino acid catabolism in plants. Molecular plant. 8 (11), 1563, 2015.

56. JOSHI R., RAMANARAO M.V., BAISAKH N. Arabidopsis plants constitutively overexpressing a myoinositol 1-phosphate synthase gene (SaINO1) from the halophyte smooth cordgrass exhibits enhanced level of tolerance to salt stress. Plant Physiol. Biochem. 65, 61, 2013.

57. SORKHEH K., SHIRAN B., KHODAMBASHI M., ROUHI V., MOSAVEI S., SOFO A. Exogenous proline alleviates the effects of $\mathrm{H}_{2} \mathrm{O}_{2}$-induced oxidative stress in wild almond species. Russian journal of plant physiology. 59 (6), 788, 2012. 
58. ZAYNAB M., FATIMA M., ABBAS S., et al. Role of secondary metabolites in plant defense against pathogens. Microb. Pathog., 2018.

59. BHATTACHARYA A., SOOD P., CITOVSKY V. The roles of plant phenolics in defence and communication during Agrobacterium and Rhizobium infection. Mol. Plant Pathol. 11 (5), 705, 2010.

60. SAED-MOUCHESHI A., PAKNIYAT H., PIRASTEHANOSHEH H., AZOOZ M. Role of ROS as signaling molecules in plants. Oxidative Damage to Plants: Elsevierpp. 585, 2014.

61. KARUPPANAPANDIAN T., MOON J.-C., KIM C., MANOHARAN K., KIM W. Reactive oxygen species in plants: their generation, signal transduction, and scavenging mechanisms. Australian Journal of Crop Science. 5 (6), 709, 2011.

62. GILL S.S., TUTEJA N. Reactive oxygen species and antioxidant machinery in abiotic stress tolerance in crop plants. Plant physiology and biochemistry. 48 (12), 909, 2010.

63. IMAHORI Y. Chapter 14 - Role of Ascorbate Peroxidase in Postharvest Treatments of Horticultural Crops. In: Ahmad P, ed. Oxidative Damage to Plants. San Diego: Academic Presspp. 425, 2014. 